\title{
Neo-liberalism and Institutionalism in the Short Life of TechBC
}

\author{
Holly Hendrigan \\ Simon Fraser University
}

\begin{abstract}
The Technical University of British Columbia (1999-2002) has received scant attention in the scholarly literature since it was folded into Simon Fraser University and became SFU's Surrey branch campus. This article uses neo-liberal and institutional theory to understand the university's economic mandate and the motivations of the staff and faculty who worked there. TechBC's legislation and oral history interviews reveal neo-liberal influence in its purpose as an economic driver of the province, academic programs intended to satisfy the high-technology labour market, willingness to collaborate with industry, corporate governance structure, and reduced government funding support. TechBC employees were drawn to working at a startup university, building an interdisciplinary curriculum, and employing new online teaching and learning methods. TechBC's institutional logic of non-conformity and its aspirations to transform the university experience accounts for its community's positive memories of the short-lived university.
\end{abstract}

RÉSUMÉ

L'Université technique de Colombie-Britannique (1999-2002) a reçu peu d'attention dans la littérature académique depuis son incorporation à l'Université Simon Fraser où elle est devenue le Campus Surrey. Cet article utilise la théorie néolibérale et institutionnelle pour comprendre le mandat économique de l'université ainsi que les motivations du personnel et des professeurs qui y ont travaillé. Les statuts de TechBC et les entrevues en histoire orale révèlent une influence néolibérale dans sa mission comme moteur économique de la province, dans les programmes universitaires destinés à satisfaire le marché du travail de haute technologie, dans la volonté de collaborer avec l'industrie, ainsi que dans la structure de gouvernance corporative et le soutien financier limité du gouvernement. Les employés de TechBC ont été incités à travailler dans une nouvelle université, à développer un programme d'études interdisciplinaires et à utiliser de nouvelles méthodes d'enseignement et d'apprentissage en ligne. La logique institutionnelle de non-conformité de TechBC et ses aspirations à transformer l'expérience universitaire expliquent le souvenir positif de sa communauté envers l'université éphémère.

The Technical University of British Columbia (TechBC) was born amid great controversy. In 1997, after reviewing the draft legislation for this new Surrey-based university, the Canadian Association of University Teachers (CAUT) and the 
Confederation of University Faculty Associations of British Columbia (CUFA-BC) issued an international boycott of the institution, objecting to the school's narrow academic focus, lack of bicameral governance, close ties with industry, and absence of faculty tenure. They placed advertisements in education trade publications, began a letter-writing campaign, and issued press releases denouncing the legislation. ${ }^{1}$ Robert Clift, CUFA-BC's executive director, questioned whether TechBC could call itself a university: such institutions "[have] to go beyond narrow job skills of the fickle hightechnology industries." ${ }^{2}$ Elsewhere, he said "it's a violation of everything for which a university is supposed to stand... Educational decisions will no longer be made for strictly educational reasons, free from any economic or financial pressures."3 Shortly thereafter, CAUT clarified in a policy statement that post-secondary education and research are public goods: "a well educated and informed citizenry is fundamental to a socially viable society." ${ }^{\prime 4}$ Universities that mimic corporations would be censured.

The boycott was a setback for the institution, which at the time employed fewer than a dozen people, ${ }^{5}$ as well as for the citizens of Surrey, who had been advocating for a university south of the Fraser River since 1991. The university immediately began discussions with CAUT, but the Technical University of British Columbia Act was proclaimed in December 1997 nevertheless. The university and CAUT eventually negotiated a settlement that included language on academic freedom, appointments, and governance; by May of 1998, CAUT had lifted its boycott. Meanwhile, TechBC's administrators and employees had an enormous amount of work to do in a short period of time, developing technological and physical infrastructure, policies, and curriculum for their first intake. Ninety-seven "learners" (TechBC's preferred term for students) arrived for orientation in August 1999.

Two years later, the school had grown to 392 students, ${ }^{6}$ but no student was admitted to TechBC after September 2001. The BC Liberal government, a coalition of conservative parties, had won seventy-seven of seventy-nine seats in the May 2001 provincial election to upset the decade-long reign of the New Democratic Party, ${ }^{7}$ and by mid-September, the new government began publicly voicing its concerns regarding the university's missed enrolment and private funding targets as well as the construction costs of the Bing Thom-Insurance Corporation of British Columbia (ICBC) development which would eventually house TechBC. ${ }^{8}$ Finance Minister Gary Farrell-Collins was particularly scathing: "the intent here was to create a monument and no cost was spared... The only difference between this and fast ferries is that this one doesn't move. It's a monument to [former ICBC chair] Bob Williams and the incompetence of the previous government." During the fall of 2001, the BC Liberals secretly put TechBC up for tender among regional, national, and international post-secondary institutions and announced on February 7, 2002, that they were shutting down TechBC and bringing in Simon Fraser University to take on TechBC's students and operate a branch campus in Surrey. The attempt by the NDP government to create a new model university was over. (For a chronology of TechBC, see Appendix A: Key Dates in TechBC's History.)

CAUT and CUFA-BC did not use the term "neo-liberalism" to explain the impetus behind the TechBC legislation, but their criticism of TechBC's market-oriented 
focus fits this theoretical framework. The purpose of this research is to examine the creation of the university in light of neo-liberalism, as well as to explore the motivations of the TechBC community that championed this new university despite CAUT's objections. Who sought employment at this shunned university? What inspired them to work there? And what accounts for the TechBC community's positive memories of their former workplace? After all, as John Levin et al. contend, scholars have roundly decried neo-liberalism as a "pernicious ideology" in education." 10 This article will discuss how TechBC's legislation had neo-liberal underpinnings and reveal how the legislation influenced TechBC's structures and policies. However, while TechBC's legislation was informed by neo-liberal values, its workforce was inspired by the prospect of transforming the educational experience for students. This paper introduces institutional theory to understand the difference between the impact of neo-liberal restructuring in established universities as compared to its impact on TechBC, a start-up.

\section{Neo-liberalism and Institutionalism}

David Harvey defines neo-liberalism as "a theory of political economic practices that proposes that human well-being can best be advanced by liberating individual entrepreneurial freedoms and skills within an institutional framework characterized by strong private property rights, free markets, and free trade."11 John Dennison and Hans Schuetze conclude that the expansion in post-secondary education that occurred in British Columbia from 1989 to 2004 was due to the neo-liberal leanings of all three governing parties - Social Credit, New Democratic Party, and BC Liberals - since the rationale behind the expanded capacity was to "educate and train a workforce with the skills necessary to fill the industrial needs of the nation." ${ }^{2}$ Many scholars have documented the phenomenon of neo-liberal reforms to higher education. ${ }^{13}$ Sheila Slaughter and Gary Rhoades have coined the term "academic capitalism" and its outcome is that "the fundamental social roles of public higher education, including providing increased upward mobility for underserved populations, have been displaced by the economic role of serving corporations' global competitiveness." 14

In addition to Dennison and Schuetze, a body of research has examined British Columbia universities and higher education policy through the lens of neo-liberal theory. Lara Lackey critiques the NDP's 1994 "Skills Now!" program for “assum[ing] that the primary purpose of education is to accommodate the demands of employers and the economy" at the expense of the broader aims of education. ${ }^{15}$ Levin et al. have documented the neo-liberal underpinnings behind the restructuring of British Columbia's community colleges, which first became university-colleges beginning in the late 1980s and were later assigned the status of special purpose universities in 2008. ${ }^{16}$ These new model universities have witnessed funding boosts for academic programs that fulfill current labour market needs, and its faculty are encouraged to engage in applied research — despite confusion regarding what "applied" research means - particularly among those who teach in social sciences and humanities departments. Robert Whiteley et al. argue that the sudden takeover of Okanagan 
College by UBC in 2004 is indicative of globalism and reveals the close ties between the government and the Okanagan power elite who benefited from real estate development when the campus expanded. ${ }^{17}$ Myka Tucker-Abramson denounces Simon Fraser University for its complicity in gentrifying Vancouver's Downtown Eastside and solving its budgetary problems by admitting increasing numbers of international students who pay premium tuition fees and argues that Royal Roads University's costrecovery business model justifies reduced government funding. ${ }^{18}$ In sum, scholars have noted the manifestation of neo-liberal policies in higher education that include decreased government support, increased engagement with private corporations, and preferential funding of academic programs that satisfy the market economy.

In addition to noting the adoption of neo-liberal practices that occurred in new model universities, Levin et al. introduced institutional theory to frame their transformations. ${ }^{19}$ James Bess and Jay Dee explain that institutionalism "suggests that organizations by accident and choice mirror the norms, values, and ideologies of the general environment in which they are embedded." ${ }^{20}$ In higher education, one can therefore expect similarities between institutions of a common type, whether they are community colleges, vocational institutes, or research universities.

Levin defines the logic of a university as having:

a tripartite mission that includes teaching, research, and service, the use of academic rank for faculty, the provision of tenure, and bicameral governance, as well as the preponderance of resources and planning devoted to baccalaureate and post-baccalaureate programming, whether in the form of master's or doctoral programs. ${ }^{21}$

Universities — " new model" or not - experience legitimacy challenges from internal and external sources when they bend to market pressures. TechBC presents an interesting case because it was born neo-liberal. CAUT very publicly voiced its legitimacy challenges; John Trueman and some interviewees suspect that other institutions in British Columbia quietly lobbied the government to close TechBC. ${ }^{22}$

TechBC received substantial newspaper coverage that documented its rise and fall, but scant attention from scholars after being dissolved. Trueman wrote a master's thesis on the institution that covers its background and events surrounding its inception and closure, published later as a monograph in $2005,{ }^{23}$ but no peer-reviewed scholarship has focused on the institution since then. Enda Brophy and Tucker-Abramson dismiss it as "a failing technical university in Surrey"; ${ }^{24}$ Jamie Brownlee is even more scornful, and factually incorrect: "this 'university' functioned like a high-technology online diploma mill supplying corporations with 'just-in-time' employees." 25 (To correct the record, TechBC never graduated a class of undergraduates, and its course offerings were not exclusively online.) Despite its short life, BC Liberal politicians such as Elayne Brenzinger were quick to praise TechBC's innovation in the provincial legislature shortly after the government announced that SFU was assuming administrative control. ${ }^{26}$ The award-winning campus and tower development catalyzed the retrofit of a downtown core in Surrey, a city known for its suburban sprawl. The SFU 
Surrey campus continues to expand its applied sciences programs. ${ }^{27}$ As TechBC was the first iteration of SFU Surrey, its short life and demise deserves closer examination.

\section{Methodology: The TechBC Memory Project and Coding Schemes}

This paper draws on oral history sources from the TechBC community to flesh out how the TechBC legislation was interpreted and implemented within the university and, in addition, reveals the personal experiences of those who worked there. As noted by Ian Greenwood, oral history can provide insights into complex organizational processes such as leadership and the social underpinnings of organizations. ${ }^{28}$ The oral sources originate from a collection of thirty oral history interviews, the TechBC Memory Project, which sought to raise awareness of the institution. After securing approval from SFU's Research Ethics Board, the author recruited participants via an email sent to SFU Surrey staff, as well as by word of mouth or "snowball" methods. Interviewees included a mix of former students, staff, faculty, and administrators, as well as a board member and even a former NDP cabinet minister who is now the president of SFU. The interviewer asked semi-structured questions that queried the participants about their experiences at TechBC, including the reasons why they were interested in working or learning there. The interviews have been fully transcribed, summarized, and indexed, and are accessible via SFU Library's digitized collections. ${ }^{29}$

This paper loosely follows Levin et al.'s methodological approach of qualitative field methods research, during which the researchers interviewed university stakeholders and triangulated the interviews with corresponding educational policy documents. ${ }^{30}$ This paper examines TechBC's legislation as the foundation for its policies, and draws on the interviews to describe how the language of the legislation was interpreted and applied. This paper uses a similar coding scheme to Levin et al.'s, which revealed themes of neo-liberal ideology: economic benefit, labour market focus, privatization, corporate governance, and reduced government funding. Motivating factors for working at TechBC were coded as well; they included risk tolerance in early and late careers, as well as an attraction to start-ups, TechBC's interdisciplinary program, and focus on online learning. Finally, Levin et al. used institutional theory to account for new model universities' “identity crisis” resulting from organizational change through the frame of institutionalism; ${ }^{31}$ this study also examines TechBC through this lens. In this case, institutional theory explains the opprobrium visited on TechBC as well as its mission of non-conformity, shared by the administration, faculty, and staff.

Where Levin et al.'s interview subjects and the institutions under examination are hidden, no interviewee of the TechBC Memory Project chose to remain anonymous. The publicly accessible nature of the interviews indubitably led to a degree of selfcensorship that might not have occurred in a study that guaranteed interviewees' anonymity. In addition, the interviews were structured as a traditional oral history without a particular research question in mind. Feminist oral historians Kathryn Anderson and Dana Jack have acknowledged that in some cases, "the scholar's search for generalizations undermine[s] the interviewer's need to attend to an individual's 
experience" 32 and Alessandro Portelli would argue that an agenda-free oral history project leads to better trust and rapport between interviewer and interviewee. ${ }^{33}$ However, it is also reasonable to assume that the general purpose of the oral history project led to some lost opportunities in making connections between TechBC, neoliberalism, and institutionalism.

\section{A Neo-liberal Institution?}

This research demonstrates that neo-liberalism is reflected to a large extent in TechBC's legislation and the oral history interviews elaborate on the policies and structures that grew out of it. These aspects include the university's purpose for economic benefit, its labour market focus, collaboration with industry, and corporate governance. The interviews also reveal another aspect of neo-liberalism, reduced government funding, which is not reflected in the language of the legislation.

Most of section two of the Technical University of British Columbia Act is worth repeating in full, and unpacking systematically. ${ }^{34}$

The purposes of the university are:

(a) to offer certificate, diploma and degree programs at the undergraduate and graduate levels in the applied, technological and related professional fields that contribute to the economic development of British Columbia,

(b) to conduct applied research and development,

(c) to provide continuing education that responds to the needs of the applied, technological and related professional fields,

(d) to create strong links with business and labour and develop programs that are relevant to, and at the forefront of, industrial and professional initiative.

Section two (a) describes TechBC's essential purpose: to offer programs in "the applied, technological and related professional fields that contribute to the economic development of British Columbia." When asked about the TechBC Act, Andrew Petter, who was in the NDP cabinet at the time (although he was not the minister of Skills, Training and Labour when the legislation was drafted), acknowledged that

the government at the time was very focused on trying to build a stronger economy. In 1997, you've got to remember that there was a big Asian meltdown in 1996. So I'm not surprised that the focus would have been on the development of a university that was very focused as being an engine for economic development. ${ }^{35}$

The Asian meltdown to which Petter refers resulted in a 38 per cent drop in exports to Japan from British Columbia, and commodity prices fell almost 40 per cent. ${ }^{36}$ Meanwhile, however, growing companies such as Crystal Decisions and Electronic Arts, which developed business software and video games respectively, had based their headquarters in the Lower Mainland, and the government and TechBC tailored 
programs to supply these industries with knowledge workers. ${ }^{37}$ TechBC's Interim Planning Council (IPC), which consisted of a mix of academic and labour leaders and community members, devised three academic programs to be taught at TechBC, known as "streams": Management and Technology, Interactive Arts and Technology, and Information Technology, and all students completed a core curriculum that included courses from each stream in their first year.

While the TechBC Act was designed to benefit the economic development of the province as a whole, another economic motive came into play after the legislation was drafted: the economic development of Surrey. Andrew Petter oversaw the Provincial Capital Commission, to which ICBC reported, as well as the portfolio of Advanced Education, Training and Technology when TechBC's Interim Planning Committee was determining the site location. Architect Bing Thom and ICBC Chair Bob Williams pitched to Petter the idea to redevelop the Central City neighbourhood of Surrey and locate the university within it. Petter agreed that this "could be a catalyst for the whole redevelopment of this declining area and be an instrument for social revitalization." 38 Jane Fee, a TechBC administrator who negotiated the lease with ICBC, reported that "the City of Surrey obviously was totally excited about the notion of redeveloping what was then known as Whalley," 39 and the city donated land to the project. Interviewees remember empty storefronts at the Surrey Place Mall ${ }^{40}$ and a high neighbourhood crime rate during their time there, in the late 1990s and early 2000s. ${ }^{41}$ The Fraser Valley Real Estate Board supported building a new university in the region from the outset and attended the inaugural meeting of the Fraser Valley University Society in $1991 .{ }^{42}$ Its members had much to gain from infrastructure spending in Surrey. ${ }^{43}$

Section two (b) of the act established TechBC's mandate to "conduct applied research and development." TechBC acknowledged this as one of its core missions and set an ambitious target to secure 50 per cent of its faculty salary budget from private sources. To achieve this goal, TechBC created a commercialization subsidiary company, the TechBC Corporation, mandated to form new companies from TechBC's intellectual property and establish research contracts with existing companies. ${ }^{44}$ The TechBC Corporation had some successes in creating companies that commercialized knowledge management, ${ }^{45}$ but came nowhere near meeting its funding target: it was widely acknowledged that two years is not enough time to build collaborative research activities with industry. Tom Calvert, vice-president, Research and External Affairs, called this 50 per cent target "totally unrealistic... most universities have real trouble bringing in large amounts of money to support their research." ${ }^{46}$ Furthermore, TechBC's academic staff were primarily concerned with building their integrated undergraduate curriculum; they would devote more time to developing their research programs later. In the end, the BC Liberal government cited TechBC's failure to meet its private funding targets as one of the reasons to shut it down.

Section two (c) of the act stated that TechBC was "to provide continuing education that responds to the needs of the applied, technological and related professional fields." To meet this purpose, TechBC's courses were developed in a novel way. Where most university courses take place over a three-month semester that results in three 
credits, TechBC parceled their courses into one-credit "modules" that were completed in five weeks. This decision was made in consultation with industry, which had told TechBC that five weeks was the maximum time commitment a technology worker could afford for professional development. ${ }^{47}$ Some TechBC educators felt that this modular approach to course delivery would probably have evolved over time: the courses would have grown longer, since they discovered that the shortened time frame led to difficulties in assessment and an overly accelerated pace of learning. ${ }^{48}$ Still, the TechBC course delivery model remains a radically different approach to teaching and learning in university education in order to attract participation from industry.

Finally, section two (e) of the act stated that TechBC's purpose was to "create strong links with business and labour and develop programs that are relevant to, and at the forefront of, industrial and professional initiative." Including language that mandates relationships with businesses in a university's legislation is unusual; it is not present in the University Act, which covers British Columbia's research-intensive and special purpose teaching universities, or in the Royal Roads University Act. ${ }^{49}$ Tom Calvert remembers "the first week I was there, I was asked to go and meet with Dianne Watts, ${ }^{50}$ just to talk about the mandate of the university that was explicitly to support business and industry." ${ }^{51}$ Dianne Cyr, a faculty member in the Management and Technology stream, acknowledged that TechBC was not interested in recruiting "traditional academics" but "[w]e wanted people who had, in the management side anyway, a good sense of business, who might have had their own consulting companies, who were eager to work with industry." 52

This imperative led to TechBC's controversial decision not to offer tenure to its faculty. Tracey Leacock, associate dean of Academic Projects explained that TechBC wanted to allow their faculty to move between academic and professional work in industry:

So they didn't see it as, "If you leave your teaching role to go work on a startup or to go take a job in industry, you are gone forever. You have left the ivory tower." It was very much, "Sure go out, get some current real-world experience, then come back in." 53

Furthermore, Arthur Fallick, associate vice-president of Academic Affairs, believed that tenure processes required that faculty publish in traditional discipline-specific journals, and the research that TechBC faculty were to be engaged in was with industry; academic journals were not the most appropriate venue for this type of multidisciplinary research and product development. ${ }^{54}$ CAUT and CUFA-BC had two concerns about the lack of tenure: first, it would have an impact on faculty's academic freedom, and second, it would lead to the practice of favouring adjuncts over permanent faculty, an increasingly common tactic among universities to reduce labour costs. ${ }^{55}$ Ultimately, after visiting TechBC, CAUT was satisfied that TechBC was issuing sufficiently long-term contracts, ${ }^{56}$ and as discussed earlier, TechBC was still developing its partnerships with industry, so no conflicts of interest regarding academic freedom had yet arisen. 
CAUT and CUFA-BC were also concerned about sections eleven and thirteen of the legislation, which covered the university's governance. Universities under the auspices of the University Act have senates; Simon Fraser University's senate, for example, is "concerned with all important matters that bear on teaching and research in the University; this includes the development of new initiatives, the formation of priorities, and the consideration and approval of policies. ${ }^{57}$ Instead of a senate, TechBC created a University Council and program advisory committees, which were mandated to consult with the president and program heads and report to the board. This decision, like that of its untenured faculty, was another aspect of TechBC's push for flexibility and its will to maintain a high degree of control over its course offerings. Donald Fisher et al. describes these structures as "a corporate model of governance," whose intention and impact was to "[move] the institution much closer to the market." ${ }^{8}$ TechBC wanted to be able to respond quickly to changes in the labour market.

The importance of TechBC's governance structure is a matter of debate. Senior TechBC administrators such as Tom Calvert argued that the lack of a senate was merely a matter of "semantics" and that the decision-making at TechBC was highly participatory. ${ }^{59}$ Indeed, all the interviewees of the TechBC Memory Project mentioned being included in decision-making. That said, Jean Watters, TechBC's second president, was attracted to TechBC because it lacked a senate, for his experience led him to believe that senates were not always accountable for their decisions, particularly ones that impact universities financially. ${ }^{60}$ While TechBC did not operate long enough for the board to micromanage the curriculum according to labour market demand, the legislation ensured that the president and the board maintained the balance of power.

Finally, scholarship that explores neo-liberalism's impact on public universities reveals the trend towards reduced government funding, a phenomenon also identified in the TechBC interviews. TechBC was designed in a similar fashion to Royal Roads University, another new-model university that the NDP established when the federal government decommissioned the former military college in 1995. Andrew Petter agreed that "there may well have been some relationship in the thinking between trying to create an alternative structure for TechBC that was to some degree influenced or at least resonated with some of the thinking around Royal Roads." ${ }^{1}$ Royal Roads targets its curriculum to mid-career professionals and provides a flexible admission program for those who lack formal educational credentials. One participant believed that Royal Roads' superior strategic planning kept its enrolment high, thus guaranteeing its survival. ${ }^{62} \mathrm{New}$ model universities were expected to recover a great proportion of their funding from tuition revenue and private sources.

TechBC's board and administration found it very difficult to operate the university within its funding allocation, and tuition revenue lagged because of low enrolment caused by space constraints while their facility was under construction. ${ }^{63}$ Sharon Shilliday, the chair of TechBC's board, wished to expand TechBC's course offerings beyond technology and add social sciences and humanities programs. She remembers being "very frustrated that the funding didn't seem to come through in comparison to other institutions. Like it just didn't seem quite fair that they weren't fully on board." ${ }^{64}$ Arthur Fallick agrees: "We were always fighting about money... 
We got some degree of freedom because we were a start-up. But it was always clear that [we] were going to have to... generate revenue — significant revenue. Significant revenue from those industry connections and from the $\mathrm{R} \& \mathrm{D}$ that was going to be done." ${ }^{65}$ In other words, the university was expected to source much of its funding from private companies.

\section{TechBC's Appeal to its Employees}

Although TechBC's legislation and lack of government support indicate that TechBC fit the model of a neo-liberal university, TechBC administrator Jane Fee protested that the spirit of an institution lies beyond the "six pages of text" expressed in the language of its statute. ${ }^{66}$ TechBC faculty and staff did not attribute enthusiasm for the legislation as their motivating factor to apply. Instead, with few exceptions, ${ }^{67}$ faculty and staff were in the early or late stages of their careers, excited to work at a start-up university that was focused on digital media as subject matter, and committed to teaching and learning via online learning platforms. They also wanted to work in interdisciplinary teams.

It thus follows that faculty interested in working at TechBC were often early or late-career academics for whom tenure was not a high priority. ${ }^{68}$ Dianne Cyr was an adjunct professor at SFU and initially had reservations about working at a start-up university with no reputation. But after her hiring interview, she reported being "really excited... It was meant to be a green field start-up university that was searching for excellence and a big focus was on online delivery which was new at that time... So I was totally sold and changed my mind completely." ${ }^{69}$ She joined as a founding faculty member of the Management and Technology stream. Jim Bizzocchi, in contrast, had worked at Capilano College for thirty years; he was enticed by a position that allowed professional growth that included a research component that would complement his experience as a college instructor: "I threw the dice and I went to a place that would allow me to explore something new in terms of my own skills." ${ }^{70}$ Similarly, Tom Calvert had been at SFU since 1972; he took a leave because "TechBC seemed to encapsulate both of my interests: the multimedia university and online learning or tele-learning." ${ }^{71}$ They were willing to put aside CAUT's concerns regarding academic freedom and job security in order to pursue ambitions that aligned with their interests in technology and pedagogy.

They were also keen to be part of a start-up, experimental university. According to Vice-president, Academic Alice Mansell, "I think all of us adhered to the belief that we were not there to be a small version of UBC or SFU or UVIC or anything like that, but we were there to experiment and to - maybe not experiment - to test, to pilot other ways of working." 72 Academic staff that had ideas on reconstructing university processes were welcome at TechBC. Director of Academic Planning Laurie Summers had discovered a passion for organizational change while revamping the medical curriculum at UBC, and TechBC offered a similar experience on a larger scale. "I realized I liked doing the revision - the change process — sort of turning things upside down and inside out." ${ }^{73}$ Chris Groeneboer had been working on the Telelearning Centre of Excellence team at SFU and wanted to integrate online 
learning with multidisciplinary work. "We'd heard about this new university being developed from the ground up, and I really wanted to be a part of designing it. The design was going to be quite different. And that really attracted me... we didn't even have faculty yet... every time we tried to do anything, [we] had to write the policy first for doing it." ${ }^{74}$ All TechBC employees were expected to contribute to its planning processes, and they greatly enjoyed this engagement with the institution.

TechBC also appealed to people interested in conducting interdisciplinary work. As described by Arthur Fallick, "TechBC had no faculties, no departments. It was a new model that was an attempt to bring together one innovative crucible, in electrical engineering, computer science, business, and interactive arts." ${ }^{75}$ Where it is common in traditional universities for colleagues to work together on curriculum for their discipline-specific programs, TechBC insisted that faculty in the Management, Information Technology, and Interactive Arts streams build their curriculum collaboratively. John Nesbit, who oversaw the creation and implementation of TechBC's course management system, recalls "the unyielding requirement that faculty plan and think about their course, and the learning activities and assessments, in a principled, systematic way." ${ }^{16}$ What Nesbit meant was that faculty did not develop the integrated curriculum in isolation; they worked in "clusters" that contained, on average, six faculty members developing one or two courses. ${ }^{77}$ Faculty were thus familiar with the learning objectives of a wide variety of courses, including those they did not teach. Chris Groeneboer recalls the team-based approach to course development having an "astounding effect" on morale, where staff were challenged intellectually and creatively as they strove to build programs that were both interdisciplinary and technologically innovative. ${ }^{78}$

Furthermore, TechBC offered its academic staff the opportunity to explore internet-based technology in course delivery. As John Nesbit explains, TechBC wanted "not [to be] a fully online university, but a university that blended online and faceto-face education in a very complementary and efficient way and one that promoted the student experience. One that would sort of fit with what they imagined at that time, what the twenty-first century would be like." ${ }^{\prime 79}$ TechBC created seven different course delivery models that were chosen depending on the course's content and pedagogical goals. Tom Calvert wanted TechBC's instructors to re-think the lecture format: "the model of sage on the stage, professor at the front of the lecture hall... we revert to the lecture model when we're out of time and we need to get through some stuff. But it's not, by no means, as effective as the constructivist approach." ${ }^{0}$ While some of the rationale for online course delivery was the school's limited space, faculty at TechBC insist that its use was not primarily intended to increase efficiency but to optimize learning. To achieve this, TechBC mandated professional development in educational technology to all instructors, and created a program-planning process that enabled them to develop and deliver their courses collaboratively within their tight timelines. ${ }^{81}$ As faculty member Jim Bizzocchi says, "If you're going to go online... you have to deal with the design of instruction systematically. You can't wing it." ${ }^{\prime 2}$ TechBC hired many learning support associates who worked on course and curriculum development as well as assessment rubrics. 
The TechBC community was focused primarily on undergraduate education. As mentioned earlier, TechBC even refused to use the term "student" because "the enterprise really was about learning more than it was about teaching. That teaching was important but it was a means to an end, and the end was learning." ${ }^{\prime 3}$ These values infused the entire organization: Shelley Sluggett, who worked in information technology, insisted that the students "were the number one reason we were all here." 84 Stephanie Chu had a newly minted graduate degree in educational psychology and left a position at SFU because of the new institution's commitment to the student experience. ${ }^{85}$ Faculty and academic staff found it challenging to develop and deliver their integrated, interdisciplinary one-credit courses within strict five-week deadlines, but their commitment was absolute. On reflection, Jane Fee, with broad administrative experience in numerous post-secondary institutions, claimed that the focus on students at TechBC was "unlike any other post-secondary institution I've ever worked in." 86 People who were attracted to TechBC were there to pilot new ways to improve teaching and learning; they derived personal satisfaction from forging an interdisciplinary curriculum and exploring best practices in delivering course content.

\section{Neo-liberalism and Institutionalism in TechBC}

From the foregoing findings, TechBC aligns with the neo-liberal phenomenon of universities restructuring in response to what Patricia Gumport calls "the increased use-value of particular knowledges in the wider society and exchange-value in certain markets." ${ }^{87}$ Slaughter and Rhodes's classic article "The Neo-Liberal University," although published shortly after TechBC's creation, reads like an instruction manual on how the university was legislated. TechBC was designed to provide job-ready graduates to the labour market in the burgeoning high technology industry and, at the local level, to provide economic stimulus to the Surrey economy. ${ }^{88}$ The new university was eager to collaborate with industry and commercialize its research, although the TechBC story also reveals that corporate co-operation takes longer than two years. TechBC was designed as a cost-effective and business-like niche university; it conformed to many of the tenets of "new managerialism" in higher education by eschewing faculty autonomy for greater managerial control. ${ }^{89}$

When the curriculum and research of universities bend to neo-liberal pressures, questions arise regarding their purpose as institutions created for the public good. ${ }^{90}$ Gumport labels this criticism as "legitimacy challenges," which echo CAUT's opposition to TechBC's legislation. Slaughter and Rhoades, for instance, document faculty resistance when asked to collaborate with industry; faculty believed that such initiatives were unscientific and refused to "[provide] a service to private companies to help them make money for their stockholders." B11 Brownlee's derisive coinage of TechBC as a digital "diploma mill"92 references David Noble's work, which criticizes schools that implement online and distance education methods. Noble was wary of universities making lucrative contracts with vendors and concerned that online technologies were being imposed from university administrators who wanted to increase efficiencies. From Noble's perspective, faculty had little to gain from teaching online courses; 
doing so would result in being "subject to all the pressures that have befallen production workers in other industries undergoing rapid technological transformation from above." ${ }^{\prime 3}$ While opposition to online learning has abated since the early 2000s, ${ }^{94}$ the CAUT Bulletin regularly features articles that document and decry the corporate influence in Canadian universities.

While Dennison and Schuetze argue that it will take time to understand the impact of neo-liberal change in universities on students and the reputations of the institutions from which they graduate, ${ }^{95}$ scholarship on British Columbia institutions that were restructured in response to neo-liberal pressures reveals negative attitudes towards the institutions in question and poor morale among those who work there. Levin et al. demonstrate that faculty in new model "special purpose" universities have difficulty understanding their institutions' new mandates, and as a result, colleagues compete for resources and fight with administration. ${ }^{96}$ Whiteley claims that students feel the impact of neo-liberalism: it is evident in large class sizes, the increasing number of international students paying premium tuition fees, and the increasing reliance on contract faculty teaching undergraduate courses. He says, "students are not immune from academic entrepreneurialism. They are being taught that if they want anything, they will have to act in their own interests. There is little sense of social responsibility, meaningful collaboration or incentive to serve others, and only an investment in self." ${ }^{\prime \prime 7}$ A neo-liberal university does not contribute to what CAUT calls a "socially viable society." 98

CAUT was therefore compelled to censure TechBC based on the language of its legislation, but those who worked there had a very different perspective on the institution. As Richard Scott says, "institutional theory reminds us that interests are institutionally defined and shaped." ${ }^{99}$ TechBC staff and faculty were interested in innovating teaching and learning and forged its institutional identity on that basis. Furthermore, Bess and Dee report that "innovation and change in higher education are often achieved by institutions that can afford to risk the charge of nonconformity." 100 The NDP government laid the groundwork for institutional non-conformity with TechBC's legislation; they then appointed board members from neighbouring post-secondary institutions such as UBC, SFU, and BCIT, who developed policies that differentiated TechBC from their own institutions. ${ }^{101}$ At the individual level, all TechBC hires fully understood that they were expected to bend the norms, values, and practices of other post-secondary institutions.

TechBC thus created its own institutional logic, which is "a way of way of thinking and behaving that reflects assumptions about the institution." 102 When logics in established organizations change, their members must reconcile new ones. ${ }^{103}$ As a start-up, however, TechBC did not employ faculty who refused to work with industry, insisted on traditional university governance structures, or resisted teaching online. Instead, its employees accepted its legislation and focused on building a new curriculum. As Jane Fee says, "our faculty that came to us had bought into [online learning], so you didn't have... the resistors that you inevitably have when you have an innovative place within a larger organization." 104

TechBC had created a unique institutional logic as a start-up university whose 
core principles included risk-taking, creativity, and collaboration. As Arthur Fallick says, "it was an amazing experience going to work every day. There was just a buzz. And we were in the second or third floor of an office complex trying to become a university that was unlike any kind of university that had been done before... people weren't quite sure what it was going to look like but they knew it was going to be new and innovative and really dynamic." 105 They were encouraged to be creative in this process and non-hierarchical, which led to a positive esprit de corps.

The positive memories former TechBC staff have of their workplace can thus be attributed to the sense of spirit and enthusiasm they brought to TechBC. They felt great camaraderie with and affection for their colleagues, and they were proud of the achievements they had begun to make in teaching and learning innovations. The institution never had the opportunity to mature and fulfil its legislative mandate to work closely with industry, nor did it graduate a cohort of undergraduates whose education and skills would have been assessed in the labour market. As an immature organization, it was still defining its core principles and did not have to reconcile any new institutional logics. The TechBC experience is now frozen in time, a three-year blip in the careers of a small community of academics and alumni. Its workers and learners still fondly remember it as a place that rewarded collaboration and creative thinking.

TechBC was unsuccessful in convincing the BC Liberal government that this experiment was worth continuing, but the closure of TechBC should not be interpreted as a failure of neo-liberal policies in higher education in British Columbia. In 2002, the Gordon Campbell government raised tuition rates and largely deregulated private post-secondary offerings, actions which further diminished government's responsibility and commitment to public education. ${ }^{106}$ To this day, both the provincial and federal governments continue slowly to re-orient universities to the marketplace. Christy Clark's 2014 Skills for Jobs Blueprint directed institutions to increase funding for trades education in support of the liquefied natural gas industry. More recently, she expanded educational opportunities in information technology. ${ }^{107}$ The Advisory Panel on Federal Support for Fundamental Science recently released its final report, known as the Naylor Report, revealing that funding for basic science has fallen far behind that of applied and partnership-based research with commercial applications. ${ }^{108}$ Where TechBC's legislation was explicitly neo-liberal, today's governments are implementing neo-liberal education policies more subtly. Citizens and scholars should continue to question the purpose of publicly funded universities and whose interests they are serving.

TechBC has a strong legacy despite its short life, for Bing Thom and Bob Williams' Central City development catalyzed a new urban ecosystem in Surrey. After TechBC was shut down, the BC Liberals eventually agreed to complete construction and within a decade, the City of Surrey had relocated its city hall there and built a new public library nearby. Within a kilometre of the SFU Surrey campus, construction is currently underway on two major projects: an expanded SFU Surrey campus that will house a sustainable energy and engineering program and a fifty-two-storey mixed-use facility that will include space for a new campus of Kwantlen Polytechnic University and a convention centre. The two-and-a-half-kilometre corridor along King 
George Highway from Surrey Memorial Hospital to SFU Surrey has been branded "Innovation Boulevard," with hopes to create a network of public and private health research sites. ${ }^{109}$ The idea to site a tower and a university adjacent to a shopping mall close to rapid transit seems like common sense today, but was ridiculed in the 1990s.

\section{Conclusion}

This paper has demonstrated that TechBC stakeholders held overlapping but distinct agendas. The government intended the university to be an engine for economic development; to achieve this, they aligned the institution's academic focus with the labour market, encouraged collaboration with industry, and codified corporate governance. Furthermore, they expected TechBC to sustain itself through private funds from the private sector. These decisions, which align with neo-liberal principles, were hardwired into the institution's norms and values, ensuring compliance with its hires. Those who worked at the university, however, had additional hopes and dreams for TechBC. While they understood that they were to educate students for the purpose of supplying the labour market with job-ready graduates, they also wanted to transform the university experience for them.

This research builds on Trueman's thesis, which recounts the story of TechBC, and also extends Levin's work on neo-liberal universities and institutionalism. This paper provides an analysis of a neo-liberal start-up university, which contrasts with the scholarly literature that examines institutions that have experienced restructuring that aligns with neo-liberal values. It also explains why its workforce held the institution in such high regard, compared with the criticism universities receive from scholars (and their own employees) in response to more incremental neo-liberal transformations. It adds to the growing body of scholarly work on neo-liberalism in British Columbia higher education and provides insight into the genesis of urban renewal and gentrification in the Whalley neighbourhood of Surrey.

The TechBC oral history interviews, which are publicly accessible, have the potential to take scholars in many different directions. While this paper examined what motivated staff and faculty to work at TechBC, future research could examine the student perspective: what compelled them to attend TechBC, a university with no reputation located inside a down-market shopping mall in an economically depressed neighbourhood? Further research could also be conducted on the reasons why academics leave secure employment for start-ups: this paper uncovers why TechBC appealed to its workforce, but the interviews did not probe deeply into the factors that compelled faculty and staff to leave their former positions. Finally, many interviewees claimed that TechBC was pedagogically innovative; future research could also examine TechBC's curriculum and course delivery models in light of current research in technology education. The Simon Fraser University Archives preserved TechBC records pertaining to both academic and administrative matters, a rich repository of documents that can enable better understanding of TechBC's place in the history of post-secondary education in British Columbia. 


\section{Acknowledgements}

The author wishes to thank the anonymous reviewers of Historical Studies in Education/ Revue d'histoire de l'éducation for their feedback on earlier drafts of this article, as well as the participants of the TechBC Memory Project for sharing their experiences. This research was supported by Simon Fraser University Library's Scholarly Digitization Fund and the Simon Fraser University Digital Humanities Innovation Lab.

\section{Notes}

1 John Trueman, Our Time Will Come Again: Tracing the Story of the Technical University of British Columbia, 3rd ed. (Vancouver: Self-published, 2005), 15.

2 Patrick Dare, "Professors Boycott New BC University: Institution Denies Academic Freedom, Critics Charge," Ottawa Citizen, September 17, 1997.

3 Barry Came, “The Tenure Trap," Maclean's, December 22, 1997, 65.

4 Canadian Association of University Teachers, "Post-Secondary Education and Research" https:/www.caut.ca/about-us/caut-policy/lists/caut-policy-statements/policy-statementon-post-secondary-education-and-research, accessed July 18, 2017.

5 Jane Fee, interview by Holly Hendrigan, December 18, 2014, TechBC Memory Project, Simon Fraser University, http://digital.lib.sfu.ca/islandora/object/techbc\%3A84/ transcript.

6 Trueman, Our Time Will Come Again, 86.

7 Jim Beatty, "Liberals Take Another Riding to Make It 77: Recount in Victoria- Hillside Takes Initial Victory from NDP, Leaving Party with Only Two Seats," Vancouver Sun, June 1, 2001.

8 Jim Beatty, "TechBC Officials to Fight for Its Survival: The Future of the Institution Is in Doubt Due to Cost Fears," Vancouver Sun, September 15, 2001; Gordon Clark, "ICBC Snaps up Surrey Place Mall: Real-Estate Source Says Deal Doesn't Make Fiscal Sense," Vancouver Province, November 13, 1998.

9 Jim Beatty, " 'Financial Disaster' Threatens TechBC Project,” Vancouver Sun, September 14, 2001. His comment regarding "fast ferries" alludes to the NDP government's mismanagement of the acquisition of two ferries. See Steve Weatherbe, "NDP's 'PellMell Rush’ Doomed Fast Cat Ferries," Sterling News Service, British Columbia, October 28, 1999.

10 John S. Levin, Aida Aliyeva, and Laurencia Walker, "From Community College to University: Institutionalization and Neoliberalism in British Columbia and Alberta," Canadian Journal of Higher Education, 46, no. 2 (2016): 166.

11 David Harvey, A Brief History of Neoliberalism (New York: Oxford University Press, 2007), 2.

12 John D. Dennison and Hans G. Schuetze, "Extending Access, Choice, and the Reign of the Market: Higher Education Reforms in British Columbia, 1989-2004," Canadian Journal of Higher Education 34, no. 3 (2004): 16. To summarize the expansion, three freestanding universities were established in the 1990s: Royal Roads University, TechBC, and the University of Northern British Columbia. Institutes that were historically vocational or artistic, namely BCIT and Emily Carr, were granted limited authority to grant degrees. Furthermore, during the 1990s and mid-2000s, Malaspina, Thompson Rivers, Fraser Valley, and Kwantlen community colleges were first upgraded to university colleges, then to "special purpose" universities. Capilano College was upgraded to a university in 2008. 
13 For example, see Stephen J. Ball, Global Education Inc.: New Policy Networks and the Neoliberal Imaginary (New York: Routledge, 2012); Jamie Brownlee, Academia, Inc.: How Corporatization Is Transforming Canadian Universities (Halifax: Fernwood Publishing, 2015).

14 Sheila Slaughter and Gary Rhoades, "The Neo-Liberal University," New Labor Forum, no. 6 (2000): 73-79; Sheila Slaughter and Gary Rhoades, Academic Capitalism and the New Economy: Markets, State, and Higher Education (Baltimore: Hopkins Fulfillment Service, 2009).

15 Lara M. Lackey, "Policy, Rhetoric, and Educational Outcomes: Interpreting Skills Now!", in Educational Outcomes for the Canadian Workplace: New Frameworks for Policy and Research, ed. Jane S. Gaskell and Kjell Rubenson (Toronto: University of Toronto Press, 2004), 177.

16 Levin, Aliyeva, and Walker, "From Community College to University"; John S. Levin, "Two British Columbia University Colleges and the Process of Economic Globalization," Canadian Journal of Higher Education 33, no. 1 (2003): 59-86.

17 Robert Whiteley, Luis L. M. Aguiar, and Tina Marten, "The Neoliberal Transnational University: The Case of UBC Okanagan," Capital \& Class 32, no. 3 (October 1, 2008): 115-42, doi:10.1177/030981680809600105.

18 Myka Tucker-Abramson, "Chile of the North?: British Columbia's Universities and the Neoliberal Revolution,” West Coast Line 63 (Spring 2009): 86-95.

19 Levin, Aliyeva, and Walker, "From Community College to University."

20 James L. Bess and Jay R. Dee, Understanding College and University Organization: Theories for Effective Policy and Practice, vol. 1 (Sterling, VA: Stylus Publishing, 2008), 141.

21 John S. Levin, Community Colleges and New Universities under Neoliberal Pressures (New York: Springer, 2017), 128.

22 Trueman, Our Time Will Come Again, 96-97; Jane Fee interview; Alice Mansell, interview by Holly Hendrigan, January 13, 2015, TechBC Memory Project, Simon Fraser University, http://digital.lib.sfu.ca/islandora/object/techbc\%3A89/transcript.

23 Trueman, Our Time Will Come Again.

24 Enda Brophy and Myka Tucker-Abramson, "Struggling Universities: Simon Fraser University and the Crisis of Canadian Public Education," TOPIA: Canadian Journal of Cultural Studies 1, no. 28 (2012): 27, https://topia.journals.yorku.ca/index.php/topia/ article/view/36198.

25 Brownlee, Academia, Inc., 129.

26 Elayne Brenzinger, Hansard - Volume 3, Number 3-Thursday, February 14, 2002, https://www.leg.bc.ca:443/documents-data/debate-transcripts/37th-parliament/3rdsession/h20214a, accessed April 6, 2017.

27 Trevor Boddy, "Surrey Central City a 'Commitment to Urbanity,' ” Vancouver Sun, 2004; Tom Zytaruk, "SFU Surrey Expanding; Trudeau Says Governments Giving \$90M for Five-Storey Building," Tri-Cities Now, November 10, 2016.

28 Ian Greenwood, "Oral History," in Sage Dictionary of Qualitative Management Research, ed. Richard Thorpe and Robin Holt (Los Angeles: Sage, 2008), 145-46.

29 TechBC Memory Project, SFU Digitized Collections, 2016, http://digital.lib.sfu.ca/ techbc-collection.

30 Levin, Aliyeva, and Walker, "From Community College to University."

31 Ibid., 170.

32 Kathryn Anderson and Dana C. Jack, "Learning to Listen: Interview Techniques and Analyses," in Women's Words: The Feminist Practice of Oral History, ed. Sherna Berger Gluck and Daphne Patai (New York: Routledge, 1991), 15.

33 Alessandro Portelli, Battle of Valle Giulia: Oral History and the Art of Dialogue (Madison, WI: University of Wisconsin Press, 1997), 35. 
34 Section 2 (d) is left out because it refers to co-operation with other post-secondary institutions, and the data suggests that TechBC had not yet acted on this mandate. British Columbia, Technical University of British Columbia Act, 1997, http://www.bclaws.ca/civix/document/id/lc/statreg/97054_pit.

35 Andrew Petter, interview by Holly Hendrigan, April 29, 2015, TechBC Memory Project, Simon Fraser University, http://digital.lib.sfu.ca/islandora/object/ techbc\%3A64/transcript.

36 Wyng Chow, "Ripple Effect Hits British Columbia," Vancouver Sun, July 24, 1998.

37 Arthur Fallick, interview by Holly Hendrigan, April 7, 2015, TechBC Memory Project, Simon Fraser University, http://digital.lib.sfu.ca/islandora/object/techbc\%3A75/ transcript.

38 Andrew Petter interview.

39 Jane Fee interview.

40 Robin Johnson, interview by Holly Hendrigan, July 13, 2015, TechBC Memory Project, Simon Fraser University, http://digital.lib.sfu.ca/islandora/object/ techbc $\% 3$ A78/transcript.

41 Tracey Leacock, interview by Holly Hendrigan, December 8, 2014, TechBC Memory Project, Simon Fraser University, http://digital.lib.sfu.ca/islandora/object/ techbc\%3A79/transcript; Dianne Cyr, interview by Holly Hendrigan, November 26, 2014, TechBC Memory Project, Simon Fraser University, http://digital.lib.sfu.ca/ islandora/object/techbc\%3A71/transcript.

42 Sharon Shilliday, interview by Holly Hendrigan, May 12, 2015, TechBC Memory Project, Simon Fraser University, http://digital.lib.sfu.ca/islandora/object/ techbc\%3A70/transcript.

43 ICBC spent \$182 million developing Central City. See Michael Kane, "Central City Sells for \$246 Million; Once Ridiculed ICBC Property Development Nets Profit of \$39 Million," Vancouver Sun, August 2, 2007.

44 Bob de Wit, interview by Holly Hendrigan, April 13, 2015, TechBC Memory Project, Simon Fraser University, http://digital.lib.sfu.ca/islandora/object/techbc\%3A80/ transcript.

45 Ibid. Bob de Wit specifically mentions companies named gavagai and knexa.com, but also admits that he cannot remember the names of other company spinoffs he developed.

46 Dianne Cyr interview; Bob de Wit interview; Tom Calvert, interview by Holly Hendrigan, September 17, 2015, TechBC Memory Project, Simon Fraser University, http://digital.lib.sfu.ca/islandora/object/techbc\%3A81/transcript.

47 Jane Fee interview.

48 Dianne Cyr interview; Tracey Leacock interview.

49 British Columbia, University Act, 1996, http://www.bclaws.ca/civix/document/id/ complete/statreg/96468_01; Royal Roads University Act, 1996, http://www.bclaws.ca/ EPLibraries/bclaws_new/document/ID/freeside/00_96409_01.

50 Dianne Watts was then a Surrey city counsellor; she later became the mayor (20052015) and was elected as the Conservative MP for South Surrey-White Rock in 2015.

51 Tom Calvert interview.

52 Dianne Cyr interview.

53 Tracey Leacock interview.

54 Arthur Fallick interview.

55 Brownlee, Academia, Inc.; Slaughter and Rhoades, "The Neo-Liberal University."

56 Trueman, Our Time Will Come Again, 15.

57 Simon Fraser University, "Senate Rules," accessed April 25, 2017, https://www.sfu.ca/ senate/senate-rules.html. 
58 Donald Fisher, Kjell Rubenson, Jacy Lee, Robert Clift, Madeleine MacIvor, and John Meredith, "The Transformation of the PSE System in British Columbia," in The Development of Postsecondary Education Systems in Canada: A Comparison Between British Columbia, Ontario, and Québec, 1980-2010, ed. Donald Fisher, Kjell Rubenson, Theresa Shanahan, and Claude Trottier (Montreal: McGill-Queen's University Press, 2014).

59 Tom Calvert interview.

60 Jean Watters, interview by Holly Hendrigan, April 8, 2015, TechBC Memory Project, Simon Fraser University, http://digital.lib.sfu.ca/islandora/object/techbc\%3A68/ transcript.

61 Fisher et al., "The Transformation of the PSE System," 71.

62 Chris Groeneboer, interview by Holly Hendrigan, February 2, 2015, TechBC Memory Project, Simon Fraser University, http://digital.lib.sfu.ca/islandora/object/techbc: 90 .

63 Tom Calvert interview.

64 Sharon Shilliday interview.

65 Arthur Fallick interview.

66 Trueman, Our Time Will Come Again, 15.

67 Bob de Wit, CEO of the TechBC Corporation, and Bernie Sheehan, TechBC's first president, are two such exceptions. De Wit was hired to commercialize TechBC's research output and form partnerships with local companies; Sheehan insisted that "TechBC is to be an economic development and job creation tool as well as an educational institution, which is why its mandate is focused on applied research" (as quoted in Dare, "Professors Boycott New BC University," A3.)

68 Jane Fee interview.

69 Dianne Cyr interview.

70 Jim Bizzocchi, interview by Holly Hendrigan, June 23, 2015, TechBC Memory Project, Simon Fraser University, http://digital.lib.sfu.ca/islandora/object/techbc\%3A91/ transcript.

71 Tom Calvert interview.

72 Alice Mansell interview.

73 Laurie Summers, interview by Holly Hendrigan, January 7, 2015, TechBC Memory Project, Simon Fraser University, http://digital.lib.sfu.ca/islandora/object/ techbc\%3A76/transcript.

74 Levin, Aliyeva, and Walker, "From Community College to University," 168.

75 Arthur Fallick interview.

76 John Nesbit, interview by Holly Hendrigan, December 11, 2014, TechBC Memory Project, Simon Fraser University, http://digital.lib.sfu.ca/islandora/object/ techbc\%3A87/transcript.

77 Tracey Leacock, Hassan Farhangi, Alice Mansell, and Karen Belfer, "Infinite Possibilities, Finite Resources: The TechBC Course Development Process" (IASTED International Conference, Computers and Advanced Technology in Education, Banff, Canada, 2001).

78 Chris Groeneboer interview.

79 John Nesbit interview.

80 Tom Calvert interview.

81 Leacock et al., "Infinite Possibilities, Finite Resources."

82 Jim Bizzocchi interview.

83 Ibid.

84 Shelley Sluggett, interview by Holly Hendrigan, November 25, 2014, TechBC Memory Project, Simon Fraser University, http://digital.lib.sfu.ca/islandora/object/ techbc\%3A66/transcript. 
85 Stephanie Chu, interview by Holly Hendrigan, February 2, 2015, TechBC Memory Project, Simon Fraser University, http://digital.lib.sfu.ca/islandora/object/techbc:65.

86 Jane Fee interview.

87 Patricia J. Gumport, "Academic Restructuring: Organizational Change and Institutional Imperatives," Higher Education 39, no. 1 (January 1, 2000): 81, doi:10.1023/A:1003859026301.

88 Tucker-Abramson, "Chile of the North?"; Whiteley, Aguiar, and Marten, "The Neoliberal Transnational University."

89 Rosemary Deem, “'New Managerialism' and Higher Education: The Management of Performances and Cultures in Universities in the United Kingdom," International Studies in Sociology of Education 8, no. 1 (March 1, 1998): 47-70, doi:10.1080/0962021980020014.

90 Whiteley, Aguiar, and Marten, "The Neoliberal Transnational University"; Brophy and Tucker-Abramson, "Struggling Universities"; Tucker-Abramson, "Chile of the North?."

91 Slaughter and Rhoades, Academic Capitalism and the New Economy, 199.

92 Brownlee, Academia, Inc., 129.

93 David F. Noble, "Digital Diploma Mills: The Automation of Higher Education," First Monday 3, no. 1 (January 5, 1998), http://journals.uic.edu/ojs/index.php/fm/article/ view/569.

94 Brownlee, Academia, Inc., 5.

95 John D. Dennison and Hans G. Schuetze, "Extending Access, Choice, and the Reign of the Market: Higher Education Reforms in British Columbia, 1989-2004," Canadian Journal of Higher Education 34, no. 3 (December 31, 2004): 13-38.

96 Levin, Aliyeva, and Walker, "From Community College to University."

97 Whiteley, Aguiar, and Marten, "The Neoliberal Transnational University."

98 Canadian Association of University Teachers, "Post-Secondary Education and Research I CAUT."

99 W. Richard Scott, "The Adolescence of Institutional Theory," Administrative Science Quarterly 32, no. 4 (1987): 508, doi:10.2307/2392880.

100 Bess and Dee, Understanding College and University Organization,143.

101 According to Sharon Shilliday, it was the board's decision, for instance, to introduce one-credit modules in order to comply with the legislation's language on collaboration with industry.

102 Levin, Community Colleges and New Universities under Neoliberal Pressures, 128.

103 Patricia H. Thornton, William Ocasio, and Michael Lounsbury, The Institutional Logics Perspective: A New Approach to Culture, Structure, and Process (Oxford: Oxford University Press, 2012).

104 Jane Fee interview.

105 Arthur Fallick interview.

106 Fisher et al., "The Transformation of the PSE System in British Columbia.

107 "BC Premier Christy Clark Reworks Jobs Plan with Focus on Tech, Innovation," Globe and Mail, http://www.theglobeandmail.com/news/british-columbia/bc-premier-christyclark-reworks-jobs-plan-with-focus-on-tech-innovation/article33713507/, accessed April 18, 2017; British Columbia, "BC's Skills for Jobs Blueprint: Re-Engineering Education and Training," 2014, https://web.archive.org/web/2017080600754/ https://www.workbc.ca/getmedia/4c54646a-93fa-4566-b148-f43a3f27b240/Booklet_ BCsBlueprint_web_140428.pdf.aspx.

108 Advisory Panel on Federal Support for Fundamental Science, "Investing in Canada's Future: Strengthening the Foundations of Canadian Research,” 2017, http:// www.sciencereview.ca/eic/site/059.nsf/vwapj/ScienceReview_April2017.pdf/\$file/ ScienceReview_April2017.pdf.

109 Krisendra Bisetty, "Surrey's Innovation Boulevard Gains Momentum," Business in Vancouver, http://biv.com/article/2013/10/surreys-innovation-boulevard-gainsmomentum, accessed April 18, 2017. 


\section{Appendix A \\ Key Dates in TechBC's History}

\begin{tabular}{|c|c|}
\hline Date & Event \\
\hline $91 / 02 / 05$ & Founding meeting of the Fraser Valley University Society \\
\hline $95 / 02 / 02$ & $\begin{array}{l}\text { Premier Mike Harcourt and Dan Miller, minister of Skills, Training, and } \\
\text { Labour, announce a new technical university to be built in Cloverdale }\end{array}$ \\
\hline $96 / 01 / 01$ & Bernard Sheehan begins as TechBC's first president \\
\hline $97 / 07 / 28$ & $\begin{array}{l}\text { CAUT and affiliates formally boycott TechBC after Bill 30, the Technical } \\
\text { University of British Columbia Act, passes third reading }\end{array}$ \\
\hline $97 / 12 / 01$ & Tom Calvert becomes Vice-president, Research and External Affairs \\
\hline $97 / 12 / 05$ & Technical University of British Columbia Act proclaimed \\
\hline $98 / 01 / 28$ & $\begin{array}{l}\text { Andrew Petter becomes minister of the reorganized Ministry of Advanced } \\
\text { Education, Training, and Technology }\end{array}$ \\
\hline $98 / 02 / 01$ & Alice Mansell is appointed Vice-president, Academic \\
\hline $98 / 02 / 18$ & $\begin{array}{l}\text { TechBC recommendation for new site in Whalley received by Minister } \\
\text { Petter }\end{array}$ \\
\hline $98 / 05 / 02$ & CAUT boycott lifted \\
\hline $98 / 07 / 20$ & Surrey Centre campus site announced \\
\hline $98 / 09 / 16$ & $\begin{array}{l}\text { President Sheehan and Alice Mansell present Academic Plan Outline to } \\
\text { Degree Program Review Committee (DPRC) }\end{array}$ \\
\hline $99 / 05 / 18$ & DPRC approves Academic Plan \\
\hline $99 / 07 / 08$ & First offer of admission to TechOne students \\
\hline $99 / 08 / 30$ & Orientation week begins for ninety-seven students \\
\hline $99 / 10 / 27$ & Incorporation of the TechBC Corporation \\
\hline $00 / 05 / 30$ & Construction equipment arrives at Surrey City Centre \\
\hline 00/09/05 & 104 students arrive for TechBC's second intake \\
\hline $01 / 05 / 22$ & $\begin{array}{l}\text { Shirley Bond appointed minister of Advanced Education under new BC } \\
\text { Liberal government }\end{array}$ \\
\hline $01 / 08 / 01$ & Jean Watters begins term as TechBC's second president \\
\hline $01 / 08 / 27$ & 240 new students arrive for first-year studies \\
\hline $01 / 09 / 13$ & $\begin{array}{l}\text { Finance Minister Gary Farrell Collins calls Surrey Centre development a } \\
\text { "fast ferry that doesn't move" (Vancouver Sun, September 14, 2001, B1) }\end{array}$ \\
\hline $01 / 09 / 21$ & $\begin{array}{l}\text { SFU President Michael Stevenson writes to Gerry Armstrong, deputy } \\
\text { minister of Advanced Education, indicating interest in assuming TechBC's } \\
\text { programs and students }\end{array}$ \\
\hline $01 / 11 / 28$ & $\begin{array}{l}\text { Advanced Education Minister Shirley Bond voices concerns regarding } \\
\text { TechBC's high cost per student compared with other institutions (Vancouver } \\
\text { Sun, September 28, B7) }\end{array}$ \\
\hline $01 / 12 / 08$ & TechBC's final business plan submitted \\
\hline $02 / 01 / 21$ & SFU submits final proposal to assume TechBC's students \\
\hline 02/02/07 & $\begin{array}{l}\text { In an open cabinet meeting, Shirley Bond announces TechBC's closure and } \\
\text { that its students will be transferred to SFU }\end{array}$ \\
\hline $02 / 02 / 11$ & TechBC's Board of Governors terminated \\
\hline $02 / 03 / 20$ & Jean Watters and Alice Mansell terminated \\
\hline $02 / 03 / 21$ & 47 TechBC employees laid off in first of three "waves" \\
\hline 02/05/09 & $\begin{array}{l}\text { Bill 50, the Advanced Education Statutes Amendment Act is introduced, } \\
\text { forming the legislative framework for repealing the TechBC Act }\end{array}$ \\
\hline $02 / 05 / 22$ & Second wave of TechBC staff layoffs \\
\hline $02 / 06 / 05$ & $\begin{array}{l}\text { SFU Surrey Short Term Planning Committee releases report regarding the } \\
\text { academic transfer of TechBC students to SFU }\end{array}$ \\
\hline $02 / 07 / 23$ & Final layoffs at TechBC \\
\hline
\end{tabular}


Date Event

02/07/31 Formal dissolution of TechBC

02/08/26 SFU Surrey students arrive for orientation week

02/09/09 SFU Surrey Grand Opening at Surrey Place Mall

Sources: Adapted from Historical Milestones of TechBC, by Bernie Sheehan, 2001. File F-1771-4-1-2, Technical University of British Columbia fonds, Simon Fraser University Archives, Burnaby, British Columbia, and John Trueman, Our Time Will Come Again: Tracing the Story of the Technical University of British Columbia, 3rd ed. (Vancouver: Self-published, 2005). 